Pamiętnik Literacki 2019, 1, s. 227-232

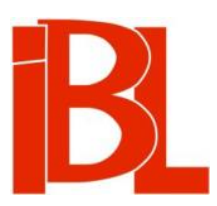

\title{
Queerowy pamiętnik
}

Rec.: Błażej Warkocki, Pamiętnik afektów z okresu dojrzewania. Gombrowicz - queer Sedgwick. Poznań-Warszawa 2018. "Nowa Humanistyka". Tom XLVI.

Marian Bielecki 


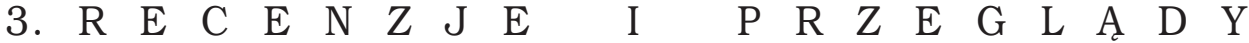

Pamiętnik Literacki CX, 2019, z. 1, PL ISSN 0031-0514

DOI: $10.18318 / \mathrm{pl} .2019 .1 .13$

MARIAN BIELECKI Uniwersytet Wrocławski

\section{QUEEROWY PAMIETNIK}

Błażej Warkocki, PAMIĘTNIK AFEKTÓW Z OKRESU DOJRZEWANIA. GOMBROWICZ - QUEER - SEDGWICK. (Recenzenci: Tomasz Basiuk, Agata Zawiszewska. Indeks: Eliza Szybowicz). (Poznań 2018). Wydawnictwo Naukowe Uniwersytetu im. Adama Mickiewicza / Warszawa 2018. Instytut Badań Literackich PAN - Wydawnictwo, ss. 304. Seria wydawnicza: „Nowa Humanistyka”. Tom XLVI.

Książka Błażeja Warkockiego należy do takich publikacji, które lubię najbardziej. Powodów mojego ukontentowania jest kilka, ale zasadniczo wynikaja one $z$ mojego konserwatywnego usposobienia i przywiązania do miar tradycyjnych. Otóż książka ta stanowi próbę monografii i to w podwójnym - by tak rzec - wymiarze. Poświęcona jest jednemu utworowi - Pamiętnikowi z okresu dojrzewania, a każdy jej rozdział przynosi możliwie całościową interpretacje poszczególnych opowiadań, co podoba mi się w dużo większym stopniu niż prace zawierajace „strukturalne” czy „tematyczne” analizy jakiegoś motywu czy aspektu utworów znajdujących się w szeregu (która to analiza stanowi praktykę sprowadzającą się ostatecznie do metafizycznej logiki wpisywania tego, co inne, w porządek tego samego: tu ten motyw wygląda trochę inaczej, ale jest też trochę podobny). Pamiętnik afektów $z$ okresu dojrzewania to także wykładnia $z$ zastosowaniem możliwie jednolitego języka interpretacyjnego.

Pod względem metodologicznym podejście Warkockiego ma, oczywiście, wszelkie cechy interdyscyplinarności, lecz nie przybiera tego - tyleż często dającego się obserwować, co niefortunnego - kształtu jakiegoś pseudopragmatycznego zestawiania wszystkiego ze wszystkim. Jednym słowem, nie sądzę, że wszystkie narzędzia teoretyczne do siebie pasują. Stanowi też recenzowana książka odważną próbę powiedzenia czegoś nowego i bynajmniej nie dającego się sprowadzić do przyczynku na temat, o którym powiedziano i wciąż się mówi dużo - czasami, niestety, aż nazbyt dużo, pospiesznie, bez przygotowania etc. ${ }^{1}$ Wreszcie

1 Dotyczy to oczywiście całej gombrowiczologii, ale i na temat tych opowiadań napisano niemało. $Z$ rzeczy dawniejszych: M. J a n i o n, Dramat egzystencji na morzu. Wstęp w: W. G o m b r o w i c z, Zdarzenia na brygu Banbury. Gdańsk 1982. - J. Ja r zę b sk ki, Gra w Gombrowicza. Warszawa 1983. - K. B a r t o s zy ń s ki, O nieważności „tego, jak było naprawdę”. (ZZrodnia z premedytacja” Witolda Gombrowicza). W zb.: Gombrowicz i krytycy. Wybór, oprac. Z. Ła p iń s ki. Kraków-Wrocław 1984. - A. Kij ow s ki, Strategia Gombrowicza. W zb.: jw. - Z. Ła pińs ki, Wstęp do metody: „Tancerz mecenasa Kraykowskiego”. W: Ja, Ferdydurke. Kraków 1997. - M. Le gi er s k i, Nowela o strukturze zagadki. W: Modernizm Witolda Gombrowicza. Warszawa 1999. - J. M a rgański, Wspomnienia z udaremnionych inicjacji. W: Gombrowicz, wieczny debiutant. Kraków 2001. - M. Głow iń s ki: Straszny piatek $w$ domu hrabiny. ( $O$ „Biesiadzie u hrabiny Kottubaj); Między obcością a swojskościa. W: Gombrowicz i nadliteratura. Kraków 2002. - K. A. G r i m s ta d, Co zdarzyło się na brygu Banbury? Gombrowicz, erotyka i prowokacja kultury. Przeł. O. Ku bińska. „Teksty Drugie” 2002, nr 3. - E. G r a c zy k, Pierwszy z debiutów. „Pamiętnik z okresu dojrzewania”. W: Przed wybuchem wstrzasnać. O twórczości Witolda Gombrowicza w okresie między- 
Pamiętnik afektów z okresu dojrzewania - last but not least - to publikacja o twórczości autora, którego jestem fanem. I to tej jej części, na której temat nigdy nie miałem odwagi ani pomysłu, żeby o niej napisać. Bo też zawsze odnosiłem wrażenie, iż Pamiętnik z okresu dojrzewania stanowi najbardziej queerową książkę Witolda Gombrowicza. Queerową w najdosłowniejszym, równocześnie zaś performatywnym sensie: dziwną oraz podejrzaną, a zarazem tę swoją ekscentryczność tematyzującą na płaszczyźnie poetyki i fabuły.

Tyle na razie uwag wstępnych i ogólnych. Mogę wszakże przyznać, że i bardziej konkretnych powodów mojego lekturowego ukontentowania było więcej. Jeden $z$ członów podtytułu (akurat mniej mi się on podoba, bo nie wydaje się ani ładny, ani nawet adekwatny) to nazwisko Eve Kosofsky Sedgwick, której wybrane koncepty stanowią dla autora podstawę metodologiczną. Pierwszy rozdział przynosi omówienie owej teorii i ten wykład trzeba uznać za ogromnie pożyteczny. Warkocki bowiem bardzo przejrzyście prezentuje wyrafinowaną teorię, wyłożoną przez Kosofsky Sedgwick - jak wie każdy, kto czytał jej teksty - przy użyciu niezwykle wyrafinowanego języka. To wprowadzenie jest jednocześnie przedstawieniem dwóch wpływowych dziś paradygmatów teoretycznych: nieźle zadomowionej w przestrzeni literaturoznawczej queer theory oraz ostatnio dość ekspansywnych affect studies. Wyznaczają one zarazem zasadnicze metodologiczne współrzędne dla odczytania Pamiętnika $z$ okresu dojrzewania zaprezentowanego w książce. Dodać by tu należało może jeszcze tylko trzeci punkt odniesienia - psychoanalizę, ponieważ wypracowana przez nią teoria paranoi to główny wytrych interpretacyjny. Chodzi, oczywiście, o następująca konstelację utworów: Pamiętniki nerwowo chorego Daniela Paula Schrebera, Psychoanalityczne uwagi o autobiograficznie opisanym przypadku paranoi (dementia paranoides) Sigmunda Freuda, Homosexual Desire Guya Hocquenghema ${ }^{2}$. A w wymienionych książkach było tak: mesjańską (zbawienie świata) i queerową (bycie kobietą oddającą się mężowi) fantazję Schrebera ujmował Freud jako paranoję stanowiąca połączenie manii wielkości i manii prześladowczej, i jako rezultat wypartego pożądania homoseksualnego. Fantazja prześladowcza dotyczy tego, kto był uprzednio obiektem miłości. W swojej reinterpretacji tego przypadku Hocquenghem zwracał uwagę na redukcję kontekstu społecznego (paragraf 175, kryminalizujący homoseksualność) i dowodził, że to homofobia rodzi paranoję. Paranoja albo sublimacja - oto przed jaką alternatywą w konsekwencji rozstrzygnięć Freudowskich

wojennym. Gdańsk 2004. - G. La n g e r, Opowiadanie Witolda Gombrowicza „Zdarzenia na brygu Banbury” jako zamaskowany tekst homoerotyczny. Przeł. I. Su ry nt. W zb.: „Patagończyk $w$ Berlinie". Witold Gombrowicz w oczach krytyki niemieckiej. Wybór, oprac. M. Zy b u ra, przy współpr. I. Surynt. Kraków 2004. - J. Franczak, „Teatrum mundi”. Witold Gombrowicz „Pamiętnik z okresu dojrzewania”. W: Poszukiwanie realności. Światopoglad polskiej prozy modernistycznej. Kraków 2007. I nowsze rzeczy: S. Kw a k, Dziewictwo i perwersja. O baśniach erotycznych Witolda Gombrowicza. Katowice 2012. - M. Mikołajec, Profanacje, rewizje - przeciw doktrynom. Dwa opowiadania z debiutanckiego tomu Witolda Gombrowicza. Katowice 2014. T. Kali ś c i a k, Statek odmieńców. O marynarskiej fantazji Witolda Gombrowicza w opowiadaniu „Zdarzenia na brygu Banbury”. W: Płeć Pantofla. Odmieńcze męskości w polskiej prozie XIX i XX wieku. Warszawa 2016. - M. P a ń c z a k, Nuda i eksces $w$ „Zdarzeniach na brygu Banbury” Witolda Gombrowicza. „Stan Rzeczy” 2016, nr 11. - K. Zi elińs ka, Kalafior i dystynkcja, czyli o tym, dlaczego o gustach się nie dyskutuje. „Biesiada u hrabiny Kottubaj” Witolda Gombrowicza. „Polisemia” 2016, nr 2.

2 D. P. S c h r e b e r, Pamiętniki nerwowo chorego wraz z suplementami i aneksem [...]. Przeł. R. D a rd a - S t a a b. Kraków 2006. - S. Fre u d, Psychoanalityczne uwagi o autobiograficznie opisanym przepadku paranoi (dementia paranoides). Przeł. R. Reszke. W: Charakter a erotyka. Oprac. R. Reszke. Warszawa 1996. - G. Hocquenghem, Homosexual Desire. Transl. by D. D a ngoor. With a new Introduction by M. Moon. Preface by J. Weeks. Durham-London 1993, s. 55-61. Te konteksty już wykorzystywano, także w gombrowiczologii: T. Ka li ś c i a k: Katastrofy odmieńców. Katowice 2011, s. 25-50; Płeć Pantofla, s. 24-35. 
stawały osoby homoseksualne. Esencjalistyczne pojmowanie homoseksualności czy tabuizacja tematu homofobii to inne w tym względzie składowe freudyzmu. Tropami wyznaczonymi przez Hocquenghema i przy wsparciu Silvana Tomkinsa oraz Melanii Klein podąża Kosofsky Sedgwick - a za nią Warkocki. Można wymienić dwa główne jej założenia przywołane przez Warkockiego: 1) „paranoja jest psychoza, która czyni wyrazistymi mechanizmy homofobii” (s. 30); 2) „Paranoja jest teorią afektów negatywnych” (s. 32). Te negatywne afekty to masochizm, wstyd, upokorzenie. Istotną rolę odgrywa jeszcze konwencja gotycyzmu, ponieważ stanowi szczególnie przydatne artystyczne medium prezentacji psychologii indywidualnej i zbiorowej, edypalnej struktury rodziny, dwoistości natury ludzkiej, erotyzacji relacji męsko-męskich i afektów, które wywołuje (s. 100). Cały czas aktualna pozostaje również koncepcja „męskiego pragnienia homospołecznego”, niuansująca kwestię relacji męsko-męskich i podkreślająca znaczenie homofobicznego szantażu jako strategii dominacji.

Z tak przysposobioną aparatura interpretacyjną Warkocki przystępuje do egzegezy debiutanckich opowiadań Gombrowicza. Na początek Tancerz mecenasa Kraykowskiego. $\mathrm{W}$ przedstawionej wykładni protagonista jest (najdosłowniej) upokorzony przez mecenasa Kraykowskiego, to zawstydzenie zaś ma wymiar i klasowy, i płciowy - ponieważ mecenas reprezentuje wyższy habitus oraz hegemoniczny wzorzec męskości. Nieźle w takim kontekście widać różnicę między winą a wstydem. Bohater-narrator nie czuje się winny, on się wstydzi. Wina odnosi się bowiem do tego, co się uczyniło, a wstyd do tego, kim się jest. Jednocześnie wstyd dokonuje interpelacji tożsamości, określa scenariusze interakcji, ale w sposób osobliwy, bo połączony z zakłóceniem identyfikacji - nie powoduje wsobnego wyobcowania, lecz zmusza do działania. Protagonista zaczyna więc prześladować Kraykowskiego performatywnym stalkingiem - szeregiem niestosowności, parodyjnym imitowaniem, voyeuryzmem, przede wszystkim zaś feminizacją, a może raczej demaskulinizacją prześladowanego. Mecenas doprowadzony do kresu psychicznego reaguje przemoca - i tym samym daje swemu prześladowcy rozkosz i spełnienie.

W następującej dalej egzegezie Pamiętnika Stefana Czarnieckiego autor recenzowanej pracy w równie ciekawy sposób pokazuje kłopoty protagonisty tak w zbiorowościach homospołecznych, jak i heterospołecznych: w szkole, w małżeństwie, w wojsku. Nie po raz pierwszy i nie ostatni w swojej książce Warkocki wskazuje intrygujący kontekst intertekstualny, w tym przypadku jest to Rasa przeklęta Marcela Prousta (s. 88). Wszelako pewien punkt niezgody odnotować muszę. Warkocki zgłasza chęć wyminięcia kwestii czasem frapującej komentatorów, czy jest to tekst antysemicki, czy jednak nie, ale mimowolnie lokuje się w samym centrum drażliwego tematu odnoszącego się do rzekomego antysemityzmu Gombrowicza. Autor recenzowanej książki deklaruje, że bardziej interesuje go problem tożsamościowy, który dotyczy przede wszystkim kwestii płci i męskości, wiadomo wszakże, iż dyskursy antysemicki i mizoginiczny często wchodzą ze sobą w związki i wzajem udzielają sobie wsparcia jako narzędzia piętna społecznego. Otóż kilka razy Warkocki powołuje się w swojej pracy na Tadeusza Kępińskiego i niekiedy ma to dobre konsekwencje, a czasem gorsze: zwłaszcza jeśli idzie o niezbyt mądrą i resentymentową drugą książkę - Witold Gombrowicz. Studium portretowe. Tak jest w rozdziale o Pamiętniku Stefana Czarnieckiego. Mam na myśli opinię dawnego i nielojalnego przyjaciela Gombrowicza, który stwierdził, iż ten nie tylko nie znał dzielnic żydowskich, ale i nie przyjaźnił się z żadnym Żydem i nawet Schulza nie lubił. Warkocki dystansuje się od Kępińskiego, lecz poświadcza, że Gombrowicz „nie interesował się szczególnie tematyką żydowską” i „antysemityzm nie był tematem, który szczególnie zajmował autora Ferdydurke [...]" (s. 80). Jest to sąd pochopny. Trudno tu o precyzyjne miary, bo nie wiadomo, od kiedy jakiś rodzaj zainteresowania należałoby uznać za „szczególny”, jednak przesłanek podważających obie niekorzystne dla Gombrowicza opinie - słabszą Warkockiego i mocniejszą Kępińskiego - można wskazać sporo. Informacje biografistów dotyczące relacji z Schulzem, ale też w Zuzanną Ginczanką, malują obraz 
jednoznaczny ${ }^{3}$. A istnieją jeszcze późniejsze komentarze Gombrowicza, z Dziennika, Testamentu i Wspomnień polskich, które tylko ktoś w tej mierze niezdolny do abstrahowania co Kępiński byłby zdolny uznać za antysemickie ${ }^{4}$. Ma się rozumieć, Warkocki nie pisze, iż Gombrowicz zaliczał się do antysemitów. Nie stwierdził tego nawet i Kępiński, chcący stworzyć sugestię - w typowym dla siebie mętnym, resentymentowym i pseudointelektualnym wywodzie - że Gombrowicz w relacji do Żydów i problematyki żydowskiej był ignorantem (z powodu niewiedzy), uzurpatorem (ze względu na skłonność do mówienia na ten temat), kłamcą ( $z$ uwagi na pozowanie na filosemitę) i posługiwał się dyskursem antysemickim (chodzi o określenie „parch”, nad którym zastanawiał się w Dzienniku) ${ }^{5}$. Niby Warkocki zastrzega, iż Kępiński to świadek wątpliwy, ale tych kilka nawiązań do jego książek wygląda bardziej na alegatywne niż sceptyczne.

Zbrodnia z premedytacja to kolejny tekst odczytany z perspektywy wstydu. Sytuacja jest podobna jak w przypadku Tancerza mecenasa Kraykowskiego. Główny bohater w resentymentowej zemście za zniewage i zawstydzenie inscenizuje śledztwo, fabrykuje watłe przesłanki i za pomocą szantażu moralnego, manipulacji językiem oraz strategii zawstydzania doprowadza do mordu i procesu symbolicznego. Do tej ciekawej wykładni dodałbym tylko dwie uwagi. Przywołując istotną i dla Gombrowicza, i dla własnych interpretacji opozycję: wnętrze-zewnętrze, Warkocki chyba sprawę upraszcza, stwierdzając, iż to kontekst klasowy decyduje o rozróżnieniu na „zbrodnię wewnętrzną” oraz „zbrodnię zewnętrzną” - ta pierwsza odnosiłaby się do ojcobójstwa, druga zaś do kradzieży lokaja. Owo rozwiązanie okazuje się zbyt proste, bo dobrze wiadomo - i Warkocki również uświadamia to sobie - że u Gombrowicza ta opozycja podlega dekonstrukcji, jej człony uwikłane są w chiazmatyczną relację i łatwo przechodzą w swoje przeciwieństwo. Warkocki niby to przeczuwa, bo już w kolejnym akapicie przywołuje wykładnię paranoi opartą na zasadzie projekcji według Freuda, używa też figury chiazmu. Krótko mówiąc: także w Zbrodni $z$ premedytacją wnętrze nie ogranicza się do tego, co psychiczne i duchowe (s. 112), podobnie jak zewnętrze nie sprowadza się do relacji z osobami spoza kręgu zasadniczych protagonistów albo do jakichś powodów nie związanych $\mathrm{z}$ intrygą. Tak czy owak, mechanizm przechodzenia obu porządków w siebie nie został - według mnie - dostatecznie przekonująco pokazany, a stanowi kluczową kwestię dotycząca rozumienia Gombrowiczowskiej „Formy”.

W interpretacji Biesiady u hrabiny Kottubaj również pojawiają się afektywne reakcje wywoływane przez klasowe relacje władzy. Trójkąt socjalny: arystokracja-mieszczaństwochłopstwo, rodzi napięcia społeczne. Uwarunkowania to niemal powieściowe: drobnomieszczański aspirant - który jednak, zauważę, wcale nie musi się nazywać Dróbek - dopuszczony do towarzystwa, onieśmielony brakiem obycia, dodatkowo zostaje zawstydzony przez kręgi arystokratyczne, przez epatowanie znakami dystynkcji. A nawet więcej, rozgrywa się tu istny spektakl wpędzania w zakłopotanie, osaczania, aż do ewentualności kanibalizmu. Sytuacja w kontekście innych opowiadań o tyle wydaje się wyjątkowa, że bohater jest paranoikiem faktycznie prześladowanym.

Następnie wypada omówienie Dziewictwa, które Warkockiemu niezmiernie się podoba. Powiada on, powołując się na opinie Ewy Graczyk i Ewy Majewskiej, iż „Gombrowicz nie

3 Zob. K. Suchanow, Gombrowicz. Ja, geniusz. T. 1. Wołowiec 2017, s. 164-165, 272-286, 298-324, 343, 406-407.

4 W. Gombrowicz: Dziennik 1953-1956. Red. nauk. J. Błoński. Kraków-Wrocław 1986, s. 126-128; Dziennik 1961-1966. Red. nauk. J. Błońs ki. Kraków-Wrocław 1986, s. 196-197; Wspomnienia polskie. - Wędrówki po Argentynie. Kraków 1996, s. 173-180.

5 T. Kę p ińs k i, Witold Gombrowicz. Studium portretowe. 1. Kraków 1988, s. 151-156. Zasadnicza teza jest następująca: „Spomiędzy różnych dziedzin, gdzie przekłamania były zwykłym sposobem opisu, a których nie możemy podać w pełnym rozmiarze, specjalne miejsce zajmuje stosunek Gombrowicza do Żydów" (ibidem, s. 151-152). 
był [...] nadmiernie wyrafinowanym analitykiem statusu kobiecości i kobiet w kulturze, a jego nawet najbardziej anarchizujący dowcip - zresztą podobnie jak u Wilde’a - zazwyczaj krążył wokół immanencji męskiej sylwetki [...]”, iż Dziewictwo „na tym tle wygląda dość oszałamiająco" (s. 149). Ja postrzegam tę pierwszą sprawę inaczej, bo mnie i nie tylko mnie Gombrowicza rozpoznania na temat kobiecości wydają się niezwykle przenikliwe oraz inspirujące (mam na myśli Iwonę, księżniczkę Burgunda, Nasz dramat erotyczny i obszerne fragmenty Dziennika). Sporo już o tym powiedziano i przypis 267 na s. 149 sygnalizuje, że Warkocki o tym dobrze wie. Wychodzi więc chyba na to, iż to kwestia upodobań, nie zaś niewiedzy. Tak czy owak, następująca dalej interpretacja jest bardzo oryginalna. Alicja okazuje się prostaczkiem rodem $z$ powiastki filozoficznej, zadającym nieskomplikowane pytania o sprawy zasadnicze - o płeć i jej związki z przemocą.

Wreszcie w najobszerniejszym rozdziale Warkocki omawia łącznie Zdarzenia na brygu Banbury i Przygody. Sporą wage przykłada do aluzji intertekstualnych i zaznacza, że swego czasu popularna opinia na temat Gombrowicza strategii „pustej intertekstualności” wymaga bardziej zasadniczej rewizji. Okazuje się bowiem - nie po raz pierwszy - iż Gombrowiczowskie nawiązania do innych tekstów nie pełnią funkcji jedynie inkrustacyjnej, ale pozwalają się inspirująco interpretować. Te, których rozszyfrowania podejmuje się Warkocki, należą bez wątpienia do najciekawszych: Banbury, anagram Tancerz (tanzman), tajemniczy inicjał „F.” i litera na karcie tytułowej. Frapująco i jakoś znajomo wypada objaśnienie banburowania: „tworzenie sobie alter ego, czy może raczej innego życia, w całkowitym oderwaniu od tego właściwego, legalnego, uczciwego. Innymi słowy to po prostu podwójne życie, dzięki któremu można na pewien czas uciec od normatywnych społecznych zobowiązań” (s. 175). Jakoś znajomo, bo od razu przypomina się „Berg” z Kosmosu, ale też autokreacje ciot z Lubiewa Michała Witkowskiego oraz kamp. I trochę dziwne, że Warkocki - jako specjalista od kontekstu, a nawet jego popularyzator ${ }^{6}$ - nie przywołał tej kategorii w swoich interpretacjach opowiadań debiutanckich. Przypuszczam, iż nie tylko „banburowanie” byłoby taktyką kampową, lecz i ogólna strategia pisarska Gombrowicza, wykorzystującego niskie architeksty powieści kryminalnej, romansowej czy marynistycznej. Tak czy owak, interpretacja właśnie tych ostatnich (marynistycznych) opowiadań wypada równie ciekawie jak poprzednie. Przygody - czytane paralelnie ze Zdarzeniami na brygu Banbury - staja się historią o inwersji i przedstawiaja sytuację dla paranoi paradygmatyczną: agon dwóch prześladujących się mężczyzn. Porównanie Zdarzeń na brygu Banbury z Billym Buddem Hermana Melville’a także wypada świetnie, bo zasygnalizowany kontekst intertekstualny pokazuje to, do czego dotychczas komentatorzy nie przywiązywali wystarczającej wagi, mianowicie uwyraźnia napięcia w relacjach męsko-męskich oraz ambiwalencje i nieoczywistości w tym, co rzekomo naturalne: w patriarchacie i heteroseksualności. Wedle wykładni Warkockiego - Zdarzenia na brygu Banbury „nie sa opowiadaniem homo e ro ty czny m, które domaga się "homoseksualnej alegorezy" czy też rozpoznania zakodowanych znaków homo s e ks ualn e go pożądania; ni e są opowieścią o ogarniającym marynarzy na statku homoseksualnym pożądaniu, któremu wszyscy ulegają. W tym sensie Banbury n i e j e st również "statkiem odmieńców". W dużo większym stopniu jest statkiem "normalsów", wyłącznie mężczyzn, na którym znajduje się coraz bardziej zastraszony odmieniec" (s. 237-238).

Nie przepadam za scholastycznymi zasadami kompozycji tekstów, ale muszę dodać kilka słów podsumowania, aczkolwiek najważniejsze rzeczy i tak zawarłem w pierwszym akapicie. Omawiana przeze mnie książka przynosi wszystkie cechy dobrze znanego przez wielu warsztatu Błażeja Warkockiego, zaprezentowane w dwóch jego poprzednich publika-

6 Mam na myśli udział w przedsięwzięciu: Kamp. Antologia przekładów. Red. P. Czaplińs ki, A. Mizerka. Kraków 2012. 
cjach $^{7}$. Autor Pamiętnika afektów $z$ okresu dojrzewania trzyma się blisko tekstu, rzadko szarżuje $\mathrm{w}$ interpretacjach, ale jeśli to czyni, to robi to $\mathrm{z}$ wyczuciem i umiarem (wtedy wykpiwa się żartem i założeniami lektury paranoicznej), jego zaś dyskurs rozpięty jest między żargonem teoretycznym (Kosofsky Sedgwick!) a luzem literackim. Ma się rozumieć, badacz pozostaje wierny swoim ideologicznym pozycjom i zaangażowanemu modelowi literaturoznawstwa, ponieważ jeden $\mathrm{z}$ kluczowych, a pewnie i najważniejszy, wątek podjęty w pracy stanowi społeczne i zawsze, niestety, aktualne zagadnienie homofobii. To, że udaje się Warkockiemu uniknąć pułapki scholastycyzmu, wcale przy tym nie powoduje, że jego literaturoznawcze podejście jest naiwne czy uproszczone. Całkiem odwrotnie, co najlepiej dokumentuje taka oto deklaracja metodologiczna niuansująca kwestie perspektywy interpretacyjnej: „nie chcę czytać Pamiętnika $z$ okresu dojrzewania jako "literatury homoseksualnej" (zwłaszcza opartej na modelu ekspresyjnym, który zakłada, że taki tekst musiał z konieczności napisać homoseksualista); nie zakładam jednak, że Gombrowicz w okresie swej wczesnej twórczości nie ma nic wspólnego z homoseksualnością” (s. 47).

Właściwie każdą interpretację Warkocki rozpoczyna od przywołania i choćby pobieżnego zrekapitulowania egzegez wcześniejszych, przynajmniej tych klasycznych. A choć ja sam nie zawsze byłbym skłonny tak postępować, bo i nie zawsze takie rozwiązanie wydaje mi się funkcjonalne (żebym został dobrze zrozumiany: przeczytać na podjęty przez siebie temat należy wszystko), to godzi się stwierdzić, iż Warkocki postępuje chwalebnie, co widać zwłaszcza na tle tylu innych prób interpretacji tekstów Gombrowicza. Można odnieść wrażenie, że autorzy są zupełnie nieświadomi tego, iż poruszone przez nich zagadnienie już omówiono lepiej i powiedziano o nim więcej.

Jako gombrowiczolog Warkocki nie obawia się perspektywy biograficznej i chętnie sięga po parateksty, zarówno te autobiograficzne, jak i eseistykę krytycznoliteracką, czyniąc je interesującymi kontekstami interpretacyjnymi. Te pierwsze - autobiograficzne (s. 43-46, 80), jako wsparcie inspiracji „studiami afektywnymi” dodatkowo radykalizują wykładnię twórczości Witolda Gombrowicza, którą na ogół traktowano jako antypsychologiczną. Jak się okazało po książce Błażeja Warkockiego - było to uproszczenie i zaniechanie.

\author{
Abstract \\ MARIAN BIELECKI University of Wrocław \\ ORCID: 0000-0003-2490-0823
}

\title{
QUEER MEMOIR
}

The text is a review of Błażej Warkocki's book Pamiętnik afektów z okresu dojrzewania. Gombrowicz queer - Sedgwick (Memoirs of Affects from a Time of Immaturity. Gombrowicz - queer - Sedgwick). The reviewer highlights the methodological innovativeness and interpretive originality of the presented readings. In his view, a skilful selection of methodological tools made here room for suggesting a coherent clarification of Gombrowicz's most eccentric and enigmatic texts.

7 B. W a r k o c ki: Homo niewiadomo. Polska proza wobec odmienności. Warszawa 2007; Różowy język. Literatura i polityka kultury na poczatku wieku. Warszawa 2013. 